\title{
man \\ Does Agricultural Mechanization Improve the Green Total Factor Productivity of China's Planting Industry?
}

\author{
Yingyu Zhu ${ }^{1}$, Yan Zhang ${ }^{1,2, *}$ and Huilan Piao ${ }^{1, *}$ \\ 1 College of Economics and Management, Shenyang Agricultural University, Shenyang 110866, China; \\ 13707631938@126.com \\ 2 Institute of Higher Education, Shenyang Agricultural University, Shenyang 110866, China \\ * Correspondence: syauzhangyan@126.com (Y.Z.); hrpark3927@syau.edu.cn (H.P.)
}

check for updates

Citation: Zhu, Y.; Zhang, Y.; Piao, H. Does Agricultural Mechanization Improve the Green Total Factor Productivity of China's Planting Industry? Energies 2022, 15, 940 https://doi.org/10.3390/en15030940

Academic Editors: Donato Morea and Eszter Toth

Received: 28 December 2021

Accepted: 25 January 2022

Published: 27 January 2022

Publisher's Note: MDPI stays neutral with regard to jurisdictional claims in published maps and institutional affiliations.

Copyright: (C) 2022 by the authors. Licensee MDPI, Basel, Switzerland. This article is an open access article distributed under the terms and conditions of the Creative Commons Attribution (CC BY) license (https:// creativecommons.org/licenses/by/ $4.0 /)$.

\begin{abstract}
Agricultural mechanization is an important factor to improve the green total factor productivity of the planting industry, which is the key way to realize the sustainable development and high-quality development of agriculture. Based on the panel data of 30 provinces in China from 2001 to 2019, this paper uses the stochastic frontier analysis method of the output-oriented distance function to measure the green total factor productivity of China's planting industry based on net carbon sinks, and empirically studies the impact of agricultural mechanization on the green total factor productivity in China's planting industry. The main findings of this paper are as follows: (1) Agricultural mechanization can promote the planting green total factor productivity significantly, and this basic conclusion is still robust after using instrumental variables and sub sample regression. (2) The path of agricultural mechanization on planting green total factor productivity is mainly reflected in technology progress and spatial spillover, while the mechanisms of operation scale expansion, factor allocation optimization and technical efficiency change are not significant. (3) With the improvement in the mechanization level, the promotion effect of mechanization on planting GTFP will become clearer. Given these findings, the paper adds considerable value to the empirical literature and provides various policy and practical implications.
\end{abstract}

Keywords: agricultural mechanization; planting industry; net carbon sinks; green total factor productivity

\section{Introduction}

The improvement in total factor productivity means that the production of the planting industry changes from factor input to efficiency improvement, which is the effective promoter of the healthy and sustainable growth of China's rural economy and high-quality agricultural development at this stage. However, with the increasing use of agricultural machinery, chemical fertilizers, pesticides, agricultural films and other modern factors, the increase in energy consumption and the consequential environmental pollution on planting production is becoming more and more prominent. Therefore, using green total factor productivity (GTFP) to incorporate environmental performance variables into the calculation of planting TFP [1], analyzing its influencing factors and clarifying its promotion mechanism can better fit the concept of agricultural sustainable development and green development, in order to realize high-quality agricultural development.

The environmental factors in the GTFP research of the planting industry can be considered from two dimensions: non-point source pollution and greenhouse gas emissions. Under the vision of carbon peak and carbon neutralization, the measurement of an undesirable output based on carbon emissions is more meaningful and practical. The existing literature to measure the carbon emissions of the planting industry mainly has the two following methods. The first method is to consider the quantity of carbon emissions purely [2] or take carbon emissions as an undesirable output to calculate GTFP [3]. However, only considering carbon emissions overemphasizes the negative side of planting production 
and ignores the positive yield and carbon sink in the process of crop growth. The second method is to adopt net carbon sinks [4] based on the dual attributes of agriculture, viz., carbon sink and carbon source. As agriculture has the dual attributes of carbon sinks and carbon source, and China's agriculture shows clear characteristics of net carbon sinks [4] (shown in Figure 1), it is a better option to use net carbon sinks as the indicator to measure carbon emissions intensity. Based on the above analysis, this paper considers net carbon sinks as environmental factors to obtain the GTFP from the perspective of input-output.



Figure 1. Planting carbon emissions and carbon sinks changes from 2001 to 2019.

Another important aspect of planting GTFP research is influencing factors, which mainly include natural environment, regional economic development, urbanization, financial support for agriculture, human capital, production risk, planting structure, land management and mechanization level [5]. As one of the most important factors to improve planting GTFP, and since the cross-regional service of agricultural machinery started in 1996 and the large-scale policy subsidy of agricultural machinery started in 2004, the process of agricultural mechanization has significantly accelerated, and the degree of agricultural production mechanization has continuously improved. On the one hand, the popularization of mechanization, accompanied by energy consumption, emits a large number of greenhouse gases. By 2018, the carbon emissions from energy consumption of agricultural machinery had become the main source of agricultural carbon emissions [6]. On the other hand, the improvement of operation accuracy and the technology spillover effect brought by mechanization reduce the unreasonable use of chemical agricultural materials, and then reduce carbon emissions. In addition, mechanization improved agricultural productivity and added net carbon sinks through technology progress and diffusion [7], allocation efficiency optimization [8], and planting structure adjustment [9]. That is, the impact of mechanization on GTFP depends on the increasing emissions effect brought by its energy consumption, the emissions reduction effect brought by the optimization of chemical agricultural inputs and the increasing sinks effect brought about by the increase in output. However, the mechanism of the impact of mechanization on GTFP has not been fully discussed and analyzed. Similar to Balk's decomposition of TFP change [10], this paper attempts to explore the impact of mechanization on GTFP from four aspects: technol- 
ogy progress, operation scale, factor allocation and technical efficiency change. Moreover, mechanization has a significant spatial spillover effect; therefore, we also further discuss the impact of mechanization on planting GTFP from the perspective of spatial spillover.

Compared with the existing research, the innovative work of this study is mainly manifested in the following two methods. Firstly, based on the characteristics of net carbon sinks in planting industry, this paper uses the multi-output stochastic frontier analysis method based on output-oriented distance function to measure planting GTFP, which better corresponds to low-carbon and high-quality agricultural development. Secondly, this paper sorts out and verifies the impact mechanism of mechanization on GTFP from five aspects: technology progress, operation scale, factor allocation, technical efficiency change and space spillover.

The remainder of this article is structured as follows: the "Literature review and mechanism analysis" section reviews the related literature and analyzes the mechanism of mechanization affecting planting GTFP. The "Method and data" section describes the methods and the nature of the data. Empirical results are presented and analyzed in the "Results" and "Discussion" sections, and the "Conclusions" section concludes the article.

\section{Literature Review and Mechanism Analysis}

\subsection{Planting GTFP}

Based on the pioneering work of Solow [11], TFP can be understood as the portion of output not explained by the number of inputs used in production. Planting GTFP is an efficiency index that reflects the quality of planting growth by taking into account environmental performance, which incorporates environmental variables into the normal measure of planting TFP [1]. The GTFP index is developed to measure the ability of an economy to produce output from a given set of inputs, while minimizing the negative environmental consequences. As it is easy to include environmental variables in the calculation of TFP, the GTFP index is a feasible and low-cost option for measuring the quality of national and regional development.

There are two methods of measuring GTFP. One is a data envelopment analysis (DEA) of the nonparametric method based on linear programming, the other is a stochastic frontier analysis (SFA) of the parametric method. These methods can trace out a production frontier, and then use the distance function to calculate the distance from the actual production state to the production frontier to express the efficiency [1]. Wang et al. (2018) calculated GTFP indexes from DEA for China's provinces from 2004 to 2015, examining the relationship between GTFP, technological progress and environmental regulation [12]. Liu et al. (2021) measured China's agricultural GTFP with DEA based on the panel data of China's provincial agriculture [13]. Compared with the DEA method, the SFA method can not only explain statistical noise, but also analyze the traditional hypothesis test, especially for the function hypothesis of the production frontier [14]. If the setting of production function form is reasonable and panel data are used, the SFA method can achieve a better estimation effect than the DEA method [15]. Frontier production function can be concluded in two ways, C-D form and translog form. The C-D form of production function assumes neutral technological progress and constant output elasticity of various factors. The translog form is flexible and inclusive, which can take into account the technological progress, substitution effect and interaction effect among input factors. Measuring GTFP involves multi-input and multi-output technology. Coelli and Perelman (1999) extended the SFA method based on the output distance function to estimate the parameters of multi output production technology [16]. Moreira and Bravo-Ureta (2016) used SFA along with the translog functional form to analyze the total factor productivity change in dairy farming in the southern part of Chile from 2005 to 2010 [17]. Liu et al. (2020) estimated China's agricultural TFP, technological progress and technical efficiency change using the provincial-level panel data of 30 provinces from 2002 to 2017 by SFA [18].

Input variables and output variables are required to calculate the planning GTFP. Input variables generally include labor, land and capital, output variables include desirable 
output and undesirable output. Crop output or output value is generally selected as the desirable output, and the undesirable output is usually considered from two dimensions: non-point source pollution and greenhouse gas emissions. For example, Xu et al. (2019) took agricultural carbon emissions as an undesired output to estimate the agricultural development efficiency in 31 provinces of China from 1998 to 2016 [19]. Liu et al. (2021) measured China's agricultural GTFP based on carbon emissions using the panel data of China's provincial agriculture [13]. Chen et al. (2021) regarded carbon emissions and agricultural non-point source pollution as undesired outputs to explore the GTFP of 30 provinces in China from 2000 to 2017 [20]. Under the vision of carbon peak and carbon neutralization, the measurement of undesirable output based on carbon emissions is more meaningful and practical. However, only considering carbon emissions overemphasizes the negative side of planting production and ignores the positive yield and carbon sinks in the process of crop growth, as crop growth needs to absorb $\mathrm{CO}_{2}$ for photosynthesis to synthesize an organic substance. Compared with 2000, China's agricultural net carbon sinks increased from 529 million tons to 747 million tons in 2016, which shows clear characteristics of agricultural net carbon sinks [4].

Planting GTFP is influenced by the internal factors and external environment. Zhan et al. (2017) showed that the effects of agricultural R\&D on China's agricultural productivity growth were positive and that human capital also played a major role in productivity growth [21]. Liu et al. (2020) revealed that agricultural labor, machinery, agricultural plastic film, and pesticides are the significant drivers of agricultural productivity [18]. Liu and Lv (2021) examined that there was a significant double threshold effect between rural human capital and agricultural GTFP under different levels of agricultural material capital and agricultural economic development with China's provincial panel data from 1993 to 2018 [22]. Fang et al. (2021) found that crop insurance had a significant positive impact on GTFP based on China's provincial panel data from 2002 to 2015 [23]. Other factors, such as regional economic development, urbanization, production risk, planting structure, land management and mechanization level, were also studied [5]. From a mechanization point of view, although it is analyzed as one of the most important factors for improving planting GTFP, the mechanism of the impact of mechanization on GTFP has not been fully explored.

This paper contributes to the existing research from the following two aspects. First, the impact of mechanization on GTFP depends on the effect of increasing emissions caused by its energy consumption, the emissions reduction effect caused by the optimization of chemical agricultural inputs and the increasing sinks effect caused by the increase in output. Based on the same attribute of carbon emissions and carbon sinks, this paper uses net carbon sinks as the environment variable to measure planting GTFP. Second, to explore the impact mechanism of mechanization on GTFP, this paper attempts to decompose the change of GTFP into four aspects: frontier technology progress, the change of returns to scale, the improvement of factor allocation efficiency and technical efficiency change. In addition, the cross-regional service of agricultural machinery is a common phenomenon in China, which implies that mechanization has a strong spatial spillover effect. Therefore, this paper verifies the impact mechanism of mechanization on GTFP from five aspects: technology progress, operation scale, factor allocation, technical efficiency change and space spillover.

\subsection{Decomposition of Planting GTFP}

Consider the stochastic frontier model proposed by Battese and Coelli (1992) [24]:

$$
Y_{i t}=f\left(X_{i t}, \beta\right) e^{v_{i t}-u_{i t}}
$$

where $Y_{i t}$ and $X_{i t}$ represent actual outputs and inputs, respectively; $f\left(X_{i t}, \beta\right)$ refers to production frontier; $v_{i t}$ and $u_{i t}$ account for stochastic error terms and non-efficiency terms, respectively.

When the logarithm and the derivative of time $t$ are taken, Equation (1) can be transformed as follows: 


$$
\frac{\partial \ln Y_{i t}}{\partial t}=\frac{\partial \ln f\left(X_{i t}, \beta\right)}{\partial t}+\sum_{j=1}^{n} \frac{\partial \ln f\left(X_{i t}, \beta\right)}{\partial \ln X_{i t j}} \times \frac{\partial \ln X_{i t j}}{\partial t}+\frac{\partial \ln e^{-u_{i t}}}{\partial t}
$$

The change of GTFP refers to the remaining part after the output change minus the change of factor input, considering environmental factors as follows:

$$
\frac{\partial \ln G T F P_{i t}}{\partial t}=\frac{\partial \ln Y_{i t}}{\partial t}-\sum_{j=1}^{n} s_{i t j} \times \frac{\partial \ln X_{i t j}}{\partial t}
$$

When Equation (2) is brought into Equation (3), the equation can be converted as follows:

$$
\frac{\partial \ln G T F P_{i t}}{\partial t}=\frac{\partial \ln f\left(X_{i t}, \beta\right)}{\partial t}+\left(R T S_{i t}-1\right) \sum_{j=1}^{n} \lambda_{i t j} \times \frac{\partial \ln X_{i t j}}{\partial t}+\sum_{j=1}^{n}\left(\lambda_{i t j}-s_{i t j}\right) \times \frac{\partial \ln X_{i t j}}{\partial t}+\frac{\partial \ln e^{-u_{i t}}}{\partial t}
$$

where $\partial \ln G T F P_{i t} / \partial t, \partial \ln f\left(X_{i t}, \beta\right) / \partial t, \partial \ln X_{i t j} / \partial t$ represent the change rate of $\ln G T F P$, output and factor $j$ with time $t$, respectively; $a_{i t j}=\partial \ln f\left(X_{i t}, \beta\right) / \partial \ln X_{i t j}, s_{i t j}=P_{i t j} \times$ $X_{i t j} / \sum_{j=1}^{n} P_{i t j} \times X_{i t j}, \lambda_{i t j}=a_{i t j} / R T S_{i t}$ represent the output elasticity, the input cost share and the output elasticity share of input $j$, respectively; $R T S_{i t}=\sum_{j=1}^{n} a_{i t j}$ represents the return to scale coefficient.

The four items on the right of Equation (4), respectively, represent the frontier technology progress, the change of return to scale, the improvement of factor allocation efficiency and technical efficiency change, viz., the change of planting GTFP can be divided into the frontier technology progress, change of return to scale, improvement of factor allocation efficiency and change of technical efficiency relative to the frontier.

\subsection{Planting GTFP Is Influenced by Mechanization through Technology Progress}

The degree of mechanization, which represents the quantity of planting machinery and the level of planting technology, can improve the production technology of the planting industry, which is an important way to improve planting output, control planting energy growth and realize carbon emissions reduction [25]. First, technology progress directly reduces carbon emissions per unit of energy consumption by improving the efficiency of traditional energy use. Second, technology progress reduces carbon emissions by changing the traditional factor input structure [26]. Third, technology progress will indirectly optimize the energy consumption structure in planting industry, increase the utilization of new renewable energy, and reduce the proportion of high-energy consumption technologies. Finally, mechanization optimizes the application level and management measures of chemical agricultural materials through experience spillover and information transmission. The optimization of management measures has the positive effect of emissions reduction [25]. In short, technology progress can effectively reduce carbon dioxide emissions and improve the GTFP of the planting industry.

\subsection{Planting GTFP Is Influenced by Mechanization through Changing Operation Scale}

On the one hand, mechanization promotes land circulation, and then changes the scale of farming land, which reduces the level of agricultural land fragmentation and changes the scale of agricultural land management [27] to reduce technology adoption costs and improve grain production efficiency. On the other hand, mechanization improves the standardization degree of operation in the process of agricultural production, causing the specialized division of labor and the production agglomeration of agricultural production, which realize the economies of scale of agricultural production. There is a significant negative correlation between the scale of farming land and the number of agricultural chemical inputs [28]. The change of chemical agricultural materials intensity will inevitably lead to the change of carbon emissions intensity. In addition, the development of mechanization makes it possible for farmers to purchase agricultural machinery services. Under the situation of rising labor costs, farmers participate in the external division of labor through machinery outsourcing services, which realize service economies of scale. In particular, 
for staple food crops, due to the difference in maturity between northern and southern crops, along with the regional specialization of continuous planting and the marketization of outsourcing services, the spatial layout structure along the latitude further strengthens the cross-regional service of agricultural machinery, which is more suitable for the service economies of scale and transforms the land-scale economy into agricultural machinery in a service-scale economy. In short, mechanization leads to the change of planting GTFP by expanding the scale of planting operation and realizing service economies of scale.

\subsection{Planting GTFP Is Influenced by Mechanization through Optimizing Resource Allocation}

The use of planting machinery can change the combination of rural labor force, land and other factors, to optimize the allocation of agricultural production factors. First, the promotion of mechanization will inevitably lead to the adjustment of the input structure of planting factors [29], including the continuous reduction in the relative price of machinery to labor, the decrease in labor input intensity in planting production, and the increase in other capital inputs such as chemical agricultural materials [30]. The change of the input structure of production factors will affect the change of carbon emissions of the planting industry, resulting in the change of GTFP of planting industry [31]. Second, the promotion of mechanization will change the planting structure. With the improvement of mechanization, the marginal labor input and management cost increase, resulting in a decrease in the planting proportion of non-grain crops, while the planting proportion of grain crops with lower labor requirements increases significantly. Compared with nongrain crops, grain crops generally have less demand for chemical agricultural materials. With the increase in the planting proportion of grain crops, the total input of chemical agricultural materials may decrease, carbon emissions will decrease, and the GTFP of the planting industry will also change.

\subsection{Planting GTFP Is Influenced by Mechanization through Improving Technical Efficiency}

In the process of mechanization, the internal differentiation caused by farmers' heterogeneity is aggravated, resulting in the widening gap of the technology utilization. In China, the main form of mechanization in planting industry is mainly reflected in the crossregional operation of agricultural machinery and the purchase of agricultural machinery services, in which the diffusion of advanced farming and harvesting technology and the overflow of planting experience is accompanied. High-efficiency agricultural operators, who have a strong resources endowment, can more easily adopt new technologies and have a stronger learning ability. Therefore, their marginal output capacity is improved more than that of low-efficiency farmers, which leads to the continuous expansion of the production frontier and depression of technical efficiency. In addition, with the continuous outflow of labor force in the process of mechanization, the quantity and quality of the rural labor force decreased. The decline in labor quality leads to a decline in agricultural management level and technical efficiency [32].

\subsection{Planting GTFP Is Influenced by Mechanization through Spatial Spillover Effect}

The impact of mechanization on planting GTFP is carried out under the background of spatial interaction, which has a strong spatial spillover effect [33]. Agricultural machinery containing agricultural technology has clear diffusion and spillover, which depends on good technological innovations and technology diffusion, the specialized division of labor and cooperation. In terms of the geographical status of the planting industry, the endowment conditions of agricultural production in adjacent areas are similar, where it is easy to observe the effect of agricultural agglomeration and enhance the agricultural-industrial network connection. The improvement in mechanization will not only lead to the change in planting GTFP in the region, but will also influence the competition and cooperation interaction with neighboring areas [34], and the planting GTFP of neighboring areas will also change. 
Based on the above analysis, this article establishes an analysis framework (shown in Figure 2) and puts forward the research hypothesis: Mechanization can improve planting GTFP, and the promotion mechanism mainly includes five aspects: technology progress, expansion of operation scale, optimization of factor allocation, improvement of technical efficiency and spatial spillover.

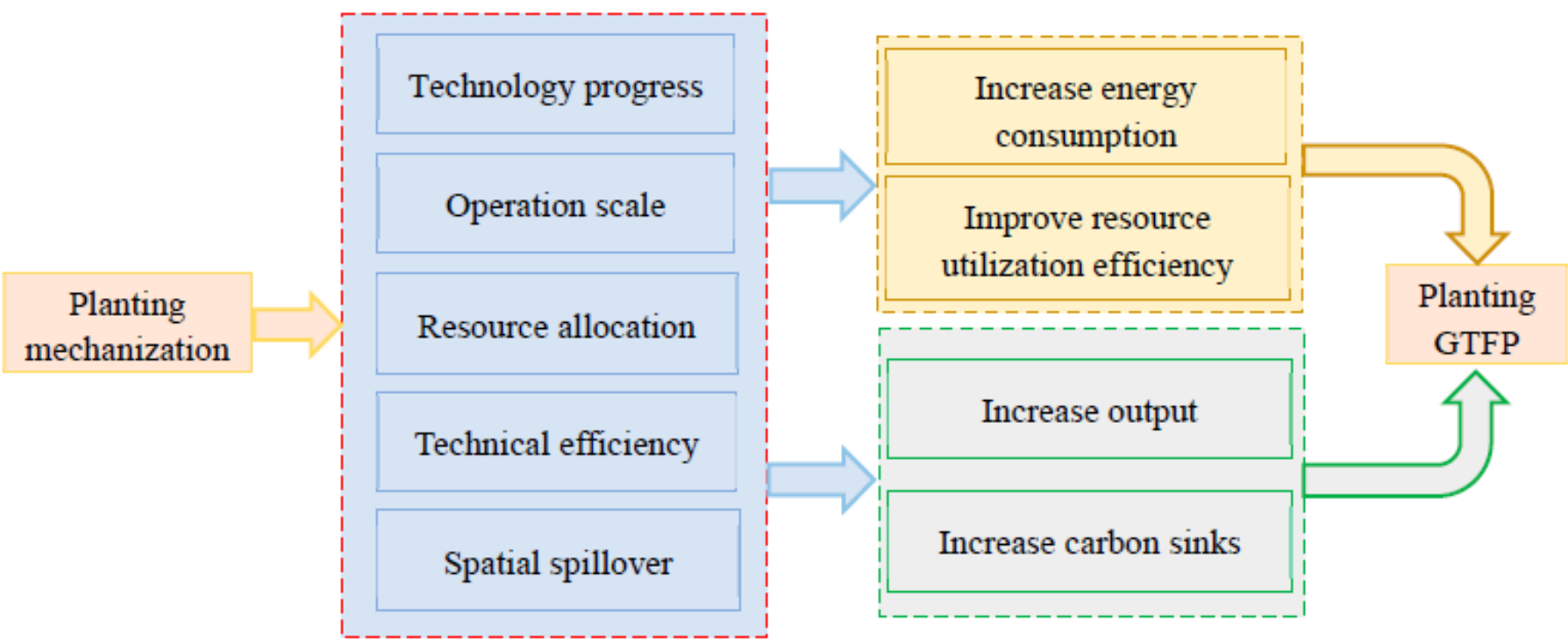

Figure 2. Influence mechanism of mechanization on planting GTFP.

\section{Methods and Data}

\subsection{Method}

\subsubsection{The Basic Econometric Model}

To test the relationship between mechanization and planting GTFP, the basic regression model is set as follows:

$$
\ln G T F P_{i t}=\alpha_{0}+\alpha_{1} X_{i t}+\sum_{j} \lambda_{j} Z_{i t j}+\mu_{i}+\eta_{t}+\xi_{i t}
$$

where GTFP $P_{i t}$ represents the planting GTFP of province $i$ at year $t ; X_{i t}$ denotes the degree of mechanization; $Z_{i t j}$ refers to control variables; $\alpha_{0}$ is the intercept term; $\alpha_{1}, \lambda_{j}$ are the estimation coefficient of each explanatory variable; $\mu_{i}$ and $\eta_{t}$ represent the fixed effect of province and year; and $\xi_{i t}$ is a stochastic error term.

\subsubsection{Recursive Model for Mediating Effect Test}

To explore the mechanism of mechanization effect on planting GTFP, based on the research methods of Hayes and Andrew [35], the recursive model for mediating effect test is set as follows:

$$
\begin{gathered}
\text { med }_{i t}=\beta_{0}+\beta_{1} X_{i t}+\sum_{j} \lambda_{j} Z_{i t j}+\mu_{i}+\eta_{t}+\xi_{i t} \\
\ln \operatorname{GTFP}_{i t}=\gamma_{0}+\gamma_{1} X_{i t}+\gamma_{2} \text { med }_{i t}+\sum_{j} \lambda_{j} Z_{i t j}+\mu_{i}+\eta_{t}+\xi_{i t}
\end{gathered}
$$

where med $_{i t}$ represents the intermediary variables, $\beta_{0}, \gamma_{0}$ are the intercept terms, and $\beta_{1}, \gamma_{1}, \gamma_{2}$ are the estimation coefficients of each variable. Equation (6) is used to test the effect of the independent variable on the intermediary variables, and Equation (7) is used to test the effect of the independent variable on the dependent variable after the introduction of intermediary variables. 


\subsubsection{Spatial Econometric Model}

Based on goodness of fit, log likelihood, likelihood ratio and Wald test, the Spatial Dubin Model is selected to verify the spatial spillover effect of mechanization on planting GTFP:

$$
\ln G T F P_{i t}=\alpha_{0}+\tau \ln G T F P_{i, t-1}+\rho W \times \ln G T F P_{i t}+\alpha_{1} X_{i t}+\alpha_{2} W X_{i t}+\sum_{j} \phi_{j} Z_{i t j}+\mu_{i}+\eta_{t}+\xi_{i t}
$$

where $W$ represents the spatial weight matrix, including the adjacent space matrix, geographical distance matrix and economic distance matrix, $\tau$ is the first-order lag coefficient of the dependent variable, $\rho$ is the spatial correlation coefficient, and $\alpha_{1}, \alpha_{2}, \phi_{j}$ are the estimated coefficients of each explanatory variable.

\subsection{Data}

\subsubsection{Dependent Variable}

This paper adopts the multi production stochastic frontier analysis method based on the output-oriented distance function [16] to estimate planting GTFP based on its significant characteristics of net carbon sinks. In terms of the production function form, the adjustment ability of planting for input factors such as land and capital is weak, and the adjustment speed is relatively slow; therefore, it is suitable to adopt a C-D production function, although the translog production function has the advantages of flexible form and good inclusiveness. The main objective of the estimation is to alleviate the endogenous problem that mainly comes from the changes in macro external factors rather than capital and labor input [36-38]. Therefore, we use the fixed-effect model to estimate and alleviate the endogenous problem by controlling the fixed effect at the provincial year level.

This paper follows the traditional literature in selecting inputs and outputs for the production function [39-41]. The output variables include the gross value of planting output (in thousand $\mathrm{CNY}$ ) and planting net carbon sinks (in thousand tons of $\mathrm{CO}_{2}$-equivalent). The calculation formula, coefficient of agricultural carbon sinks and carbon emissions are based on the research of Tian et al. (2014) [42] and Chen et al. (2019) [43]. The change rate of outputs in China's planting is shown in Figure 3. The main input variables of agricultural production are labor, land, machinery and fertilizer. Labor (in thousands) is measured as the number of employees in the primary industry multiplied by the proportion of the total output value of planting industry in the total output value of $f$ primary industry. Land (in thousand hectares) refers to the sown area reflecting the actual utilization of the cultivated land. Machinery (in thousand kilowatts) is measured by the total power of agricultural machinery multiplied by the proportion of the total output value of planting industry in the total output value of primary industry. Fertilizer (in thousand tons) refers to the sum of the gross weight of nitrogen, phosphate, potash, and complex fertilizers. The change rate of inputs in China's planting is shown in Figure 4. 


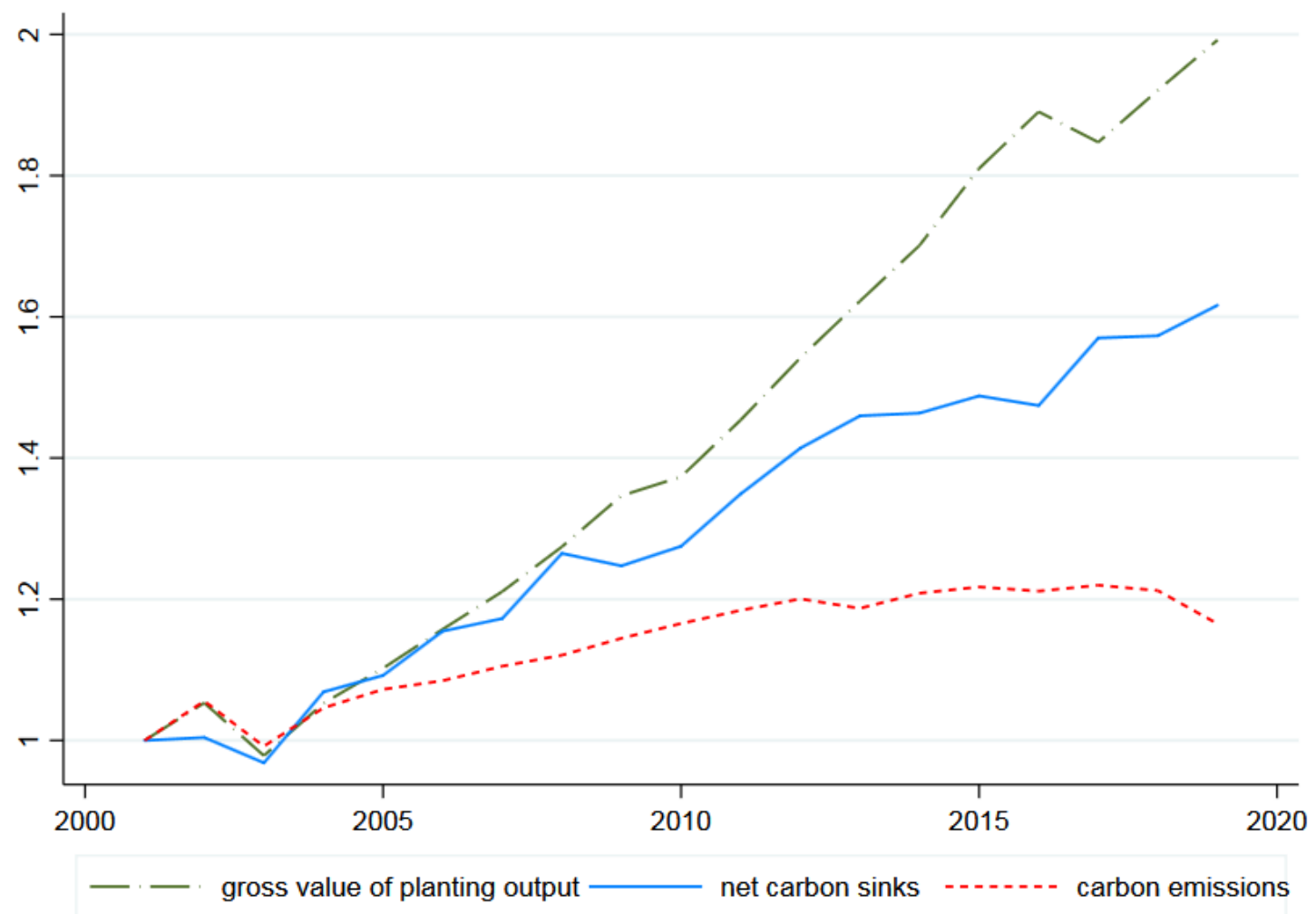

Figure 3. Change rate of planting outputs from 2001 to 2019.

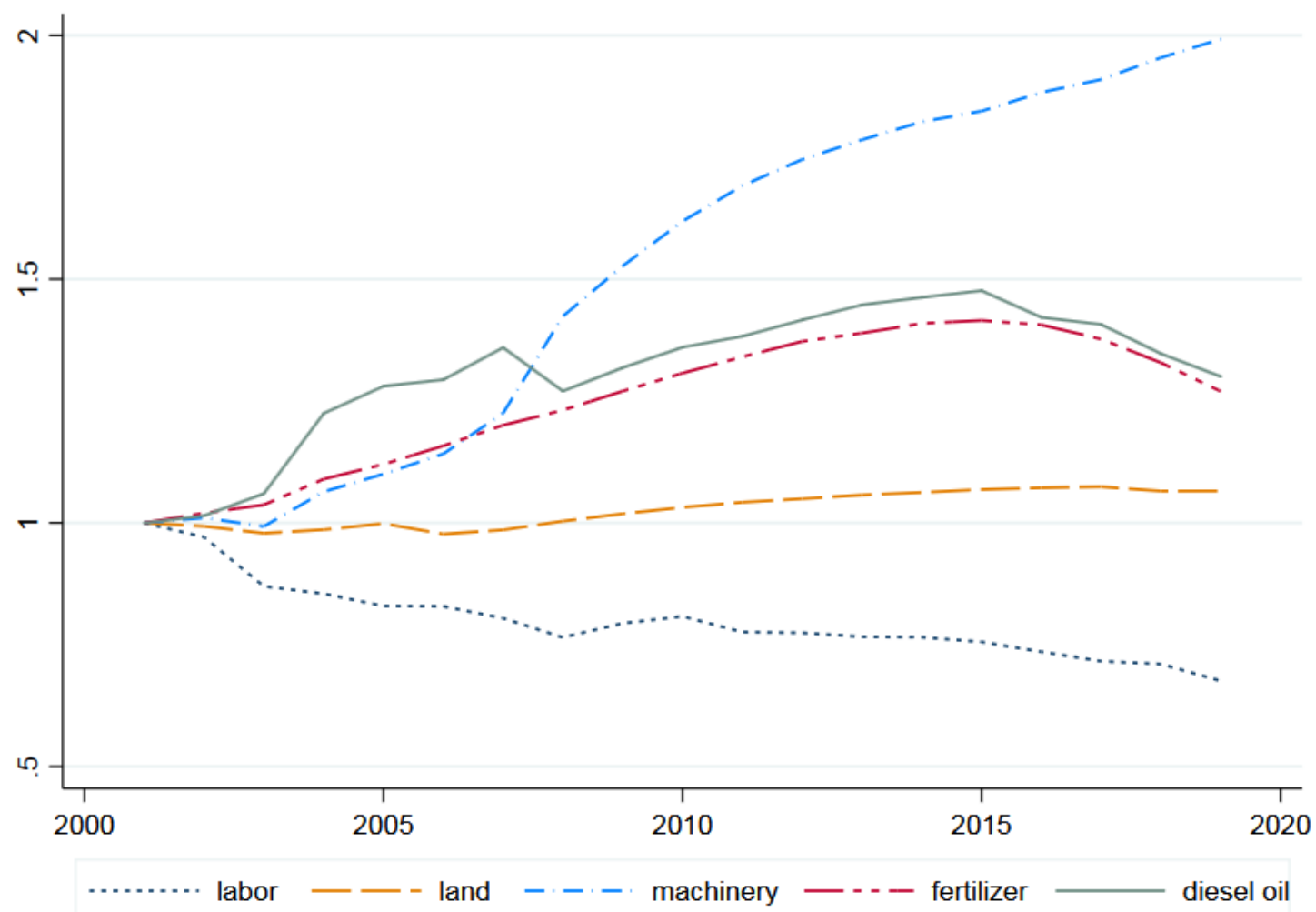

Figure 4. Change rate of planting inputs from 2001 to 2019. 


\subsubsection{Independent Variable}

This paper adopts the comprehensive mechanization rate of crop cultivation and harvest as the core explanatory variable, which is measured by the weighted average value of machine tillage rate, machine sowing rate and machine yield rate (the weights are 0.4 , 0.3 and 0.3 , respectively).

\subsubsection{Instrument Variable}

There may be some endogenous problems in the mechanization and planting GTFP for two reasons: first, there may be missing variables that affect planting GTFP. Although this paper tries to control a series of characteristic variables related to planting environment in the empirical model, such as agricultural planting structure and rural human capital, it is still unable to completely control the omitted variables in theory. Second, mechanization and planting GTFP may be simultaneous. Provinces with a high planting GTFP level are usually areas with a high level of factor endowment. Due to the high level of regional development and high relative labor price, these areas will adapt to the requirements of local agricultural development through the large-scale application of mechanized operation, to improve the mechanization level in their region. Therefore, this paper uses the transportation infrastructure, viz., the proportion of grade road mileage and cultivated land area in the region, as the instrument variable to alleviate the estimation error caused by the possible endogenous problems. Transportation infrastructure will not have a direct impact on planting output and net carbon sinks, but it can improve the level of planting mechanization by improving the road conditions of agricultural machinery operation and reducing traffic costs; the transportation infrastructure variable meets the requirements that are highly related to explanatory variables but not related to error terms.

\subsubsection{Intermediary Variables}

This paper studies the transmission mechanism of mechanization to GTFP from the perspectives of technology progress, operation scale, resource allocation and technical efficiency change. Technology progress is represented by the total power of machinery per unit area, operation scale is measured as the ratio of cultivated land area to planting population, resource allocation is characterized by the ratio of fertilizer application per unit area to labor input, and technical efficiency is expressed by the reciprocal of the distance between actual output and frontier output.

\subsubsection{Control Variables}

The main control variables are agricultural land management scale, agricultural planting structure, rural human capital, regional economic development level, part-time employment of labor force, production risk and urban-rural income gap. Agricultural land management scale (in hectare per household) is represented by the ratio of cultivated land area to rural households, and its square term is introduced to examine the possible threshold of agricultural land scale. Agricultural planting structure is characterized by the ratio of grain sowing area to crop sowing area. Rural human capital (in years) is measured as the average number of years of education of the rural population. Regional economic development level (in CNY per person) is represented by per capita GDP. The proportion of the wage income of rural residents is selected to represent the part-time employment of labor force. Production risk refers to the ratio of the affected area to the total sown area of crops. The urban-rural income gap is measured as the ratio of disposable income of urban residents to rural residents.

\subsection{Data Description}

Since the impact of mechanization on planting production is persistent and spills over, the long-term panel data are indispensable for the study of planting GTFP. To ensure that the research samples change as much as possible, the data used in this study are the provincial-level planting outputs and inputs of China's 30 mainland provinces, taken from 
2001 to 2019 due to the lack of some statistical data of Hong Kong, Macao, Taiwan and Tibet. The data come from the China Rural Statistical Yearbook and China Agricultural Machinery Yearbook. Taking into account the price factor, the variables related to price are deflated according to the price level in 2001. The descriptive statistics of variables are shown in Table 1.

Table 1. Descriptive statistics.

\begin{tabular}{|c|c|c|c|c|c|c|}
\hline Variable Type & Variable & Abbreviation & Mean & Std. Dev. & Min & $\operatorname{Max}$ \\
\hline Dependent variable & Log(planting GTFP) & $\ln G T F P_{i t}$ & 4.850 & 0.388 & 3.931 & 6.007 \\
\hline Independent variable & mechanization & $\operatorname{mac}$ & 0.441 & 0.231 & 0.014 & 1 \\
\hline \multirow{2}{*}{ Instrument variable } & transportation infrastructure & $\inf$ & 32.707 & 22.153 & 4.568 & 121.937 \\
\hline & technology progress & tp & 0.558 & 0.266 & 0.139 & 1.416 \\
\hline \multirow{6}{*}{ Intermediary variables } & operation scale & os & 9.766 & 6.716 & 2.236 & 44.132 \\
\hline & resource allocation & $\mathrm{ra}$ & 0.385 & 0.172 & 0.062 & 1.173 \\
\hline & technical efficiency & tec & 0.678 & 0.153 & 0.438 & 0.986 \\
\hline & agricultural land management scale & sca & 6.843 & 6.026 & 0.929 & 30.643 \\
\hline & agricultural planting structure & pst & 0.651 & 0.129 & 0.328 & 0.971 \\
\hline & rural human capital & hum & 7.372 & 0.727 & 4.811 & 9.731 \\
\hline \multirow[t]{4}{*}{ Control variables } & regional economic development level & agdp & 0.011 & 0.006 & 0.003 & 0.033 \\
\hline & part-time employment of labor force & ccj & 15.327 & 21.269 & 0.062 & 76.300 \\
\hline & production risk & ris & 0.227 & 0.155 & 0.000 & 0.936 \\
\hline & urban-rural income gap & inc & 2.874 & 0.572 & 1.850 & 5.120 \\
\hline
\end{tabular}

\section{Results}

In this section, the impact of mechanization on GTFP is further analyzed. Figure 5 plots the binary relationship between mechanization and lnGTFP. Clearly, lnGTFP is positively correlated with mechanization. This means that the regions with a higher degree of mechanization are likely to perform more efficiently in GTFP.

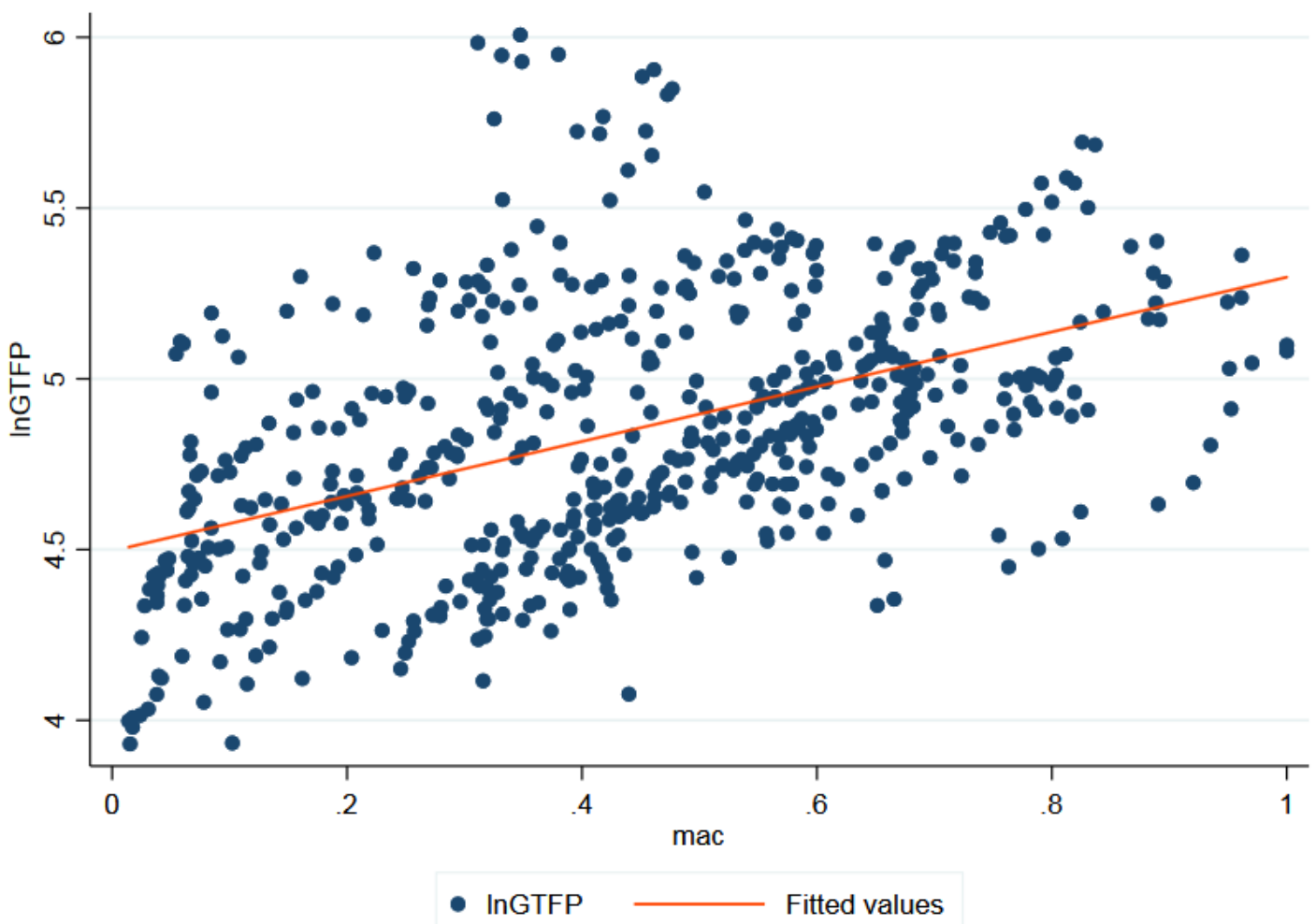

Figure 5. The binary relationship between mechanization and lnGTFP. 


\subsection{The Basic Regression Results}

The basic regression results are shown in Table 2. The OLS regression results show that mechanization plays a clear role in promoting planting GTFP. The second-stage regression results of 2SLS, measured using an instrument variable, demonstrate that mechanization and planting GTFP still show the same positive relationship, and the coefficient is significant at the level of $1 \%$. The regression results of the first stage show that there is a clear positive correlation between the instrument variable and independent variable, which passes the significance test of $1 \%$, whether adding control variables or not, which means that there is a positive correlation between the regional transportation infrastructure level and mechanization. The regression results of the first stage meet the correlation hypothesis of the instrumental variable. Among the control variables, agricultural land scale and rural human capital play a clear role in promoting planting GTFP, and there is a negative relationship between production risk and planting GTFP. The results provide empirical evidence for our hypothesis, viz., the degree of mechanization and planting GTFP shows a positive relationship.

Table 2. Results of the relation between mechanization and planting GTFP.

\begin{tabular}{|c|c|c|c|c|c|}
\hline \multirow{2}{*}{$\begin{array}{c}\text { Method } \\
\text { Model }\end{array}$} & \multicolumn{2}{|c|}{ OLS } & \multicolumn{3}{|c|}{ 2SLS } \\
\hline & (1) & (2) & & (3) & (4) \\
\hline mac & $\begin{array}{c}1.356^{* * *} \\
(0.130)\end{array}$ & $\begin{array}{c}0.512^{* * *} \\
(0.161)\end{array}$ & & $\begin{array}{l}1.611^{* * *} \\
(0.068)\end{array}$ & $\begin{array}{c}1.386^{* * *} \\
(0.308)\end{array}$ \\
\hline sca & & $\begin{array}{c}0.011^{* * *} \\
(0.003)\end{array}$ & & & $\begin{array}{c}0.007^{* *} \\
(0.003)\end{array}$ \\
\hline pst & & $\begin{array}{l}0.396^{*} \\
(0.225)\end{array}$ & & & $\begin{array}{l}-0.068 \\
(0.214)\end{array}$ \\
\hline hum & & $\begin{array}{c}0.077^{* * *} \\
(0.023)\end{array}$ & & & $\begin{array}{c}0.002 \\
(0.029)\end{array}$ \\
\hline gdp & & $\begin{array}{c}32.690^{* * * *} \\
(5.990)\end{array}$ & & & $\begin{array}{l}12.205 \\
(9.733)\end{array}$ \\
\hline ccj & & $\begin{array}{l}0.002 * * * \\
(0.001)\end{array}$ & & & $\begin{array}{c}0.001 \\
(0.000)\end{array}$ \\
\hline ris & & $\begin{array}{l}-0.182^{* * *} \\
(0.053)\end{array}$ & & & $\begin{array}{l}-0.099 * \\
(0.053)\end{array}$ \\
\hline inc & & $\begin{array}{c}-0.076^{* *} \\
(0.035)\end{array}$ & & & $\begin{array}{c}0.017 \\
(0.043)\end{array}$ \\
\hline R-squared & 0.706 & 0.812 & & 0.681 & 0.735 \\
\hline $\begin{array}{l}\text { Coefficient of IV } \\
\text { in the first stage }\end{array}$ & & & & $\begin{array}{c}0.007^{* * *} \\
(0.000)\end{array}$ & $\begin{array}{l}0.002 * * * \\
(0.000)\end{array}$ \\
\hline $\begin{array}{l}\text { Value } F \text { in the } \\
\text { first stage }\end{array}$ & & & & 231.970 & 18.700 \\
\hline Fixed province & & & Yes & & \\
\hline Fixed year & & & Yes & & \\
\hline Observations & & & 570 & & \\
\hline Provinces & & & 30 & & \\
\hline
\end{tabular}

Note: ${ }^{*}{ }^{* *},{ }^{* * *}$ : statistically significant at $10 \%, 5 \%$ and $1 \%$, respectively; Standard error in parentheses.

\subsection{Mechanism Test}

According to the previous analysis of the transmission mechanism of mechanization on planting GTFP, this paper uses the recursive model for a mediating effect test from the perspectives of technology progress, operation scale, resource allocation and technical efficiency, and uses Spatial Dubin Model to study the transmission mechanism from the perspective of spatial spillover.

Table 3 reports the results of the mechanism test. Models (1), (2), (3) and (4) show the regression results of the first step. The regression coefficients in Models (1), (2) and (3) are positive and all pass the significance test of $1 \%$, indicating that the popularization of mechanization has significantly improved the level of planting technology, expanded the scale of 
planting operation and improved the factor allocation structure. The coefficient in Model (4) is negative, which shows that technical efficiency declines with the improvement of mechanization. The other models show the regression results of the second step. Model (5) shows that the impact coefficient of mechanization is 0.512 when no intermediary variable is added. Models (6), (7), (8) and (9) show that, after adding the variables of technological progress, operation scale, factor allocation and technical efficiency, respectively, the impact coefficient of mechanization on planting GTFP decreases, but the significance of the coefficient does not change significantly. After adding all intermediary variables to Model (10), the coefficient and significance of mechanization decreased, while the technology progress were still significant at the $1 \%$ level, indicating that the intermediary variable of technology progress selected in this paper plays a partial mediating role. The coefficient of operation scale is positive but fails to pass the significance test at the $10 \%$ level, indicating that the mechanism of operation scale is not established. This is mainly because the planting industry shows the characteristics of decreasing or constantly returning to scale $[44,45]$. The coefficient of factor allocation is positive but also fails to pass the significance test at the $10 \%$ level, indicating that the mechanism of factor allocation is not established. The main reason for this is that the farmers are rational, economic people, who realize the optimization of factor resource allocation through the learning effect and experience accumulation longterm production practices. The coefficient of technical efficiency is negative, indicating that the mechanism of technical efficiency change is not established, which illustrates that the contribution of technical efficiency to planting GTFP is negative. The possible reason is that farmers were not able to adjust their agricultural management methods in time according to technology changes brought by mechanization, resulting in a reduction in the degree of refinement of agricultural production.

Table 3. Results of the transmission mechanism of mechanization to planting GTFP.

\begin{tabular}{|c|c|c|c|c|c|c|c|c|c|c|}
\hline $\begin{array}{c}\text { Dependent } \\
\text { Variable }\end{array}$ & tp & os & ra & tec & \multicolumn{6}{|c|}{$\operatorname{lnGTFP}$} \\
\hline Model & (1) & (2) & (3) & (4) & (5) & (6) & (7) & (8) & (9) & (10) \\
\hline mac & $\begin{array}{c}0.453^{* * *} \\
(0.056)\end{array}$ & $\begin{array}{c}4.268^{* * *} \\
(3.338)\end{array}$ & $\begin{array}{c}0.431^{* * *} \\
(0.138)\end{array}$ & $\begin{array}{c}-0.016^{* *} \\
(0.007)\end{array}$ & $\begin{array}{c}0.512 * * * \\
(0.161)\end{array}$ & $\begin{array}{c}0.167^{* * *} \\
(0.063)\end{array}$ & $\begin{array}{c}0.301^{* * *} \\
(0.058)\end{array}$ & $\begin{array}{l}0.217^{* * *} \\
(0.063)\end{array}$ & $\begin{array}{c}0.505^{* * *} \\
(0.161)\end{array}$ & $\begin{array}{l}0.131^{* *} \\
(0.066)\end{array}$ \\
\hline tp & & & & & & $\begin{array}{c}0.184^{* * *} \\
(0.033)\end{array}$ & & & & $\begin{array}{c}0.176^{* * *} \\
(0.030)\end{array}$ \\
\hline os & & & & & & & $\begin{array}{c}0.016^{* * *} \\
(0.004)\end{array}$ & & & $\begin{array}{l}0.007 \\
(0.004)\end{array}$ \\
\hline ra & & & & & & & & $\begin{array}{c}0.522 * * * \\
(0.100)\end{array}$ & & $\begin{array}{c}0.063 \\
(0.057)\end{array}$ \\
\hline tec & & & & & & & & & $\begin{array}{l}-0.449 \\
(0.477)\end{array}$ & $\begin{array}{l}-0.467 \\
(0.069)\end{array}$ \\
\hline R-squared & 0.683 & 0.747 & 0.562 & 0.181 & 0.812 & 0.752 & 0.750 & 0.760 & 0.813 & 0.930 \\
\hline $\begin{array}{l}\text { Control } \\
\text { variable }\end{array}$ & \multicolumn{10}{|c|}{ Controlled } \\
\hline $\begin{array}{l}\text { Fixed } \\
\text { province }\end{array}$ & \multicolumn{10}{|c|}{ Yes } \\
\hline Fixed year & \multirow{2}{*}{\multicolumn{10}{|c|}{$\begin{array}{l}\text { Yes } \\
570\end{array}$}} \\
\hline Observations & & & & & & & & & & \\
\hline Provinces & \multicolumn{10}{|c|}{30} \\
\hline
\end{tabular}

Note: ${ }^{* *}, * * *$ statistically significant at $5 \%$ and $1 \%$, respectively; Standard error in parentheses.

There are spillover and re feedback effects in spatial panel regression, so direct parameter estimation can easily causes errors in the results. Only through calculating the direct effect and spatial spillover effect in the spatial econometric model, and consolidating this to obtain the total effect, can we comprehensively describe the interactive relationship between dependent variables and independent variables. Table 4 reports the results of the spatial regression model under different spatial weight matrices, such as adjacency space matrix, geographical distance matrix and economic distance matrix. From the results of the spatial coefficient and spatial spillover effect, mechanization has a significant spatial spillover effect on planting GTFP, viz., the level of mechanization in adjacent areas will 
have a positive impact on planting GTFP in this region. It reflects that mechanization is not limited to serve a single region but may also expand the market space of mechanized operation with the help of differences in crop maturity. Therefore, mechanized operation not only has a promoting relationship with local planting GTFP, but also has a positive impact on the planting GTFP in surrounding regions due to the spatial spillover of its cross-regional operation.

Table 4. Results of the spatial effect of mechanization on planting GTFP.

\begin{tabular}{cccc}
\hline & Adjacency Matrix & $\begin{array}{c}\text { Geographical } \\
\text { Distance Matrix }\end{array}$ & Economic Distance Matrix \\
\hline Model & $\mathbf{( 1 )}$ & $\mathbf{( 2 )}$ & $\mathbf{( 3 )}$ \\
\hline spatial coefficient & $0.213^{* * *}$ & $0.354^{* * *}$ & $0.4199^{* * *}$ \\
& $(0.054)$ & $(0.087)$ & $(0.063)$ \\
LR_Direct & $0.178^{* * *}$ & $0.125^{*}$ & $(0.069)$ \\
& $(0.066)$ & $(0.074)$ & $0.648^{* * *}$ \\
LR_Indirect & $0.823^{* * *}$ & $1.182^{* * *}$ & $(0.209)$ \\
LR_Total & $(0.114)$ & $(0.277)$ & $0.848^{* * *}$ \\
R-squared & $1.000^{* * *}$ & $1.307 * * *$ & $(0.222)$ \\
& $(0.119)$ & $(0.275)$ & 0.607
\end{tabular}

\subsection{Heterogeneity Analysis}

To verify the relationship between mechanization and planting GTFP in different regions, the samples were divided into two groups: main grain-producing areas and non-grain-producing areas. The main grain-producing areas include 13 provinces such as Liaoning and Jilin. Models (1) and (2) in Table 5 show that there are differences in the effect of mechanization on the planting GTFP in different regions. In the main grain-producing areas, the coefficient of the impact of mechanization on planting GTFP is 0.704 , and the corresponding elasticity is 0.138 , that is, for each percentage point increase in mechanization level, the planting GTFP increases by $0.138 \%$; while the coefficients and elasticities of nongrain-producing areas are 0.335 and 0.128 , respectively. This may be caused by the high level of planting machinery in the main grain-producing area.

To verify the validity of our inference according to the agricultural industry standard in China, this paper further divides the development stage of agricultural mechanization into three stages: primary (mechanization rate less than $40 \%$ ), intermediate (40\% to $70 \%$ ) and advanced (more than $70 \%$ ) to investigate whether there are differences in the impact of mechanization on planting GTFP at different development levels. The results in Models (3)-(5) verify the above speculation. With the improvement in the mechanization level, the regression coefficient continues to increase, i.e., the effect of different levels of mechanization on the improvement of planting GTFP will be different. When the degree of mechanization is low, the use of machinery in planting production is relatively small, and farmers will give priority to those that can greatly reduce factor input, mechanization is mainly manifested in the effect of technological progress. With the improvement in the mechanization level, its contribution to the improvement of planting GTFP through the path of technology progress has a decreasing trend of marginal utility. However, at this stage, the substitution effect of machinery on labor is increasing, a large proportion of the labor force is liberated from the planting industry sector, and the improvement of the standardization of mechanical operation leads to the professional division of labor and the industrial agglomeration of planting production, which causes the factor allocation effect and economies of scale effect of mechanization to appear. Meanwhile, the application and popularization of mechanization are generally carried out in the form of cross-regional operations. With the diffusion of production technology and experience spillover, the improvement effects of technical efficiency and spatial spillover begin to play an impor- 
tant role. Therefore, with the improvement in mechanization level, its role in improving planting GTFP is becoming more significant.

Table 5. Results of heterogeneity analysis.

\begin{tabular}{|c|c|c|c|c|c|}
\hline & $\begin{array}{c}\text { Non-Grain-Producing } \\
\text { Area }\end{array}$ & $\begin{array}{c}\text { Main Grain-Producing } \\
\text { Area }\end{array}$ & $\begin{array}{c}\text { Primary } \\
\text { Mechanization }\end{array}$ & $\begin{array}{l}\text { Intermediate } \\
\text { Mechanization }\end{array}$ & $\begin{array}{c}\text { Advanced } \\
\text { Mechanization }\end{array}$ \\
\hline Model & (1) & (2) & (3) & (4) & (5) \\
\hline mac & $\begin{array}{l}0.335^{* * *} \\
(0.091)\end{array}$ & $\begin{array}{l}0.704^{* * *} \\
(0.082)\end{array}$ & $\begin{array}{l}0.826^{* * *} \\
(0.132)\end{array}$ & $\begin{array}{l}0.929 * * * \\
(0.121)\end{array}$ & $\begin{array}{l}1.139 * * * \\
(0.356)\end{array}$ \\
\hline sca & $\begin{array}{c}0.013^{* * *} \\
(0.002)\end{array}$ & $\begin{array}{l}-0.006 \\
(0.007)\end{array}$ & $\begin{array}{l}-0.002 \\
(0.007)\end{array}$ & $\begin{array}{l}-0.021 * \\
(0.011)\end{array}$ & $\begin{array}{c}0.013^{* * *} \\
(0.003)\end{array}$ \\
\hline pst & $\begin{array}{l}0.925^{* * *} \\
(0.182)\end{array}$ & $\begin{array}{l}0.342^{* *} \\
(0.145)\end{array}$ & $\begin{array}{c}0.326 \\
(0.216)\end{array}$ & $\begin{array}{l}0.291 * \\
(0.161)\end{array}$ & $\begin{array}{l}-0.427 \\
(0.416)\end{array}$ \\
\hline hum & $\begin{array}{c}0.116^{* * *} \\
(0.025)\end{array}$ & $\begin{array}{c}0.047^{* * *} \\
(0.017)\end{array}$ & $\begin{array}{c}0.009 \\
(0.022)\end{array}$ & $\begin{array}{c}0.066^{* * *} \\
(0.020)\end{array}$ & $\begin{array}{c}0.063 \\
(0.052)\end{array}$ \\
\hline agdp & $\begin{array}{c}17.849^{* * *} \\
(6.709)\end{array}$ & $\begin{array}{l}40.117^{* * *} \\
(5.786)\end{array}$ & $\begin{array}{l}50.180^{* * *} \\
(11.338)\end{array}$ & $\begin{array}{l}11.986 \\
(7.946)\end{array}$ & $\begin{array}{l}-5.040 \\
(9.779)\end{array}$ \\
\hline ccj & $\begin{array}{c}0.003^{* * *} \\
(0.000)\end{array}$ & $\begin{array}{c}0.002^{* * *} \\
(0.000)\end{array}$ & $\begin{array}{c}0.002^{* * *} \\
(0.001)\end{array}$ & $\begin{array}{c}0.001^{* * *} \\
(0.000)\end{array}$ & $\begin{array}{l}0.002 * * \\
(0.001)\end{array}$ \\
\hline ris & $\begin{aligned}- & 0.224^{* * *} \\
& (0.052)\end{aligned}$ & $\begin{aligned}- & 0.172^{* * * *} \\
& (0.046)\end{aligned}$ & $\begin{array}{l}-0.110^{* *} \\
(0.050)\end{array}$ & $\begin{aligned}-0.192^{* * *} \\
(0.049)\end{aligned}$ & $\begin{array}{c}-0.223 * \\
(0.114)\end{array}$ \\
\hline inc & $\begin{array}{l}-0.045 \\
(0.036)\end{array}$ & $\begin{array}{l}-0.051^{* *} \\
(0.023)\end{array}$ & $\begin{array}{l}-0.032 \\
(0.026)\end{array}$ & $\begin{array}{l}-0.061^{* *} \\
(0.031)\end{array}$ & $\begin{array}{l}-0.074 \\
(0.112)\end{array}$ \\
\hline R-squared & 0.867 & 0.789 & 0.744 & 0.755 & 0.763 \\
\hline $\begin{array}{l}\text { Fixed } \\
\text { province } \\
\text { Fixed year }\end{array}$ & \multicolumn{5}{|c|}{ Yes } \\
\hline Observations & 323 & 247 & 251 & 241 & 78 \\
\hline Provinces & 17 & 13 & 23 & 25 & 11 \\
\hline
\end{tabular}

Note: ${ }^{*},{ }^{* *},{ }^{* * *}$ : statistically significant at $10 \%, 5 \%$ and $1 \%$, respectively; Standard error in parentheses.

\section{Discussion}

\subsection{Relationship between Mechanization, GTFP and Energy-Environment Performance}

The basic regression results show that mechanization plays a clear role in promoting planting GTFP, which is consistent with the research results of Liu et al. [18]. However, there are also viewpoints that mechanization leads to a decline in environmental performance. For example, in the research of Jiang et al. [46], based on the study sample of China's 30 provinces from 2000 to 2017, the conclusion was drawn that the development of agricultural mechanization had a significant negative effect on energy-environment performance, which meant that the regions with high penetration rates of agricultural mechanization usually had a low energy-environment performance.

Intuitively, the greater energy consumption and $\mathrm{CO}_{2}$ emissions caused by agricultural machinery, the worse the performance of agricultural energy utilization and environmental pollution in the study region. However, crop growth requires absorbed $\mathrm{CO}_{2}$; therefore, agriculture has the attribute of carbon sinks, and the effect of carbon sinks is greater than that of carbon emissions. Therefore, the evaluation of agricultural environmental performance should not minimize the energy consumption or carbon emissions but maximize net carbon sinks. In addition, the inconsistency between the two results may be due to the differences between measurement indicators, i.e., GTFP is not equal to energy-environment performance. GTFP is a comprehensive indicator, which not only reflects environmental factors, but also reflects the quality of planting development. In fact, China's agricultural GTFP showed a fluctuating growth trend [13], while the value of energy-environment performance showed a downward trend in the research of Jiang et al. [46].

As discussed in the Literature section, the impact of mechanization on GTFP depends on three aspects: the increasing emissions effect caused by its energy consumption, the emissions reduction effect caused by the optimization of chemical agricultural inputs 
and the increasing sinks effect caused by the increase in output. From the perspective of input-output, GTFP is reduced by the first aspect and improved through the latter two aspects. Our results show that the effect of the latter two aspects is greater than that of the first; although mechanization consumes more energy, it brings a stronger positive effect. Therefore, we should not suggest reducing the level of mechanization to better environmental performance but should continue to improve the degree of mechanization and attempt to reduce the energy consumption per unit of mechanical power.

\subsection{The Impact Mechanism of Mechanization on GTFP}

The mechanism test results show that one of the mechanism paths of mechanization on planting GTFP is reflected in technology progress. At present, China's agricultural mechanization technology is the leading agricultural technology, and the level of mechanization represents the quantity of agricultural machinery and the level of agricultural technology. Technology progress is the most important factor to improve TFP. In the pioneering work of Solow [11], TFP is usually used to represent technology progress. Therefore, GTFP is mainly driven by technology progress; therefore, the mechanism path of technology progress is the most significant characteristic in this regard, which is verified in the research of Liu et al. [18]. On the one hand, technology progress improves the efficiency of traditional energy utilization and changes the traditional factor input structure. On the other hand, technology progress optimizes the energy consumption structure by increasing the utilization of renewable energy.

The mechanism test results show that another mechanism path of mechanization on planting GTFP is reflected in spatial spillover. Following about 20 years of popularization, the cross-regional service of agricultural machinery is a common phenomenon in China. In particular, for staple food crops such as wheat, due to the north-south difference in planting time and maturity time, large agricultural machinery often works across regions; therefore, it has a strong spatial spillover effect. Meanwhile, cross-regional operation spreads advanced farming experience and management technology, and further strengthens the spatial spillover effect.

The mechanism path of operation scale expansion is unconfirmed. Many studies found that agriculture satisfied the assumption of constant returns to scale, namely, that agricultural output increased at the same rate as an increase in agricultural input $[18,44,45]$. This means that agricultural GTFP has not improved, although the operation scale of land was expanded by land transfers. The possible reasons for this are as follows: first, land fragmentation, that is, the phenomenon of small-scale farming, is still the main form of agricultural operation in China; second, farmers who trade outside of their own land may be farmers with higher GTFP, and the scale effect is offset by the low GTFP of farmers who transfer it onto their land.

The mechanism path of factor allocation optimization is not verified. Generally speaking, the change trend of GTFP is consistent with that of allocation efficiency [18]. However, in our research, the mechanism path of factor allocation optimization was not verified. The possible reason for this is that farmers are rational, economic people [47], and their current factor allocation state is already optimal through the effect of learning and the accumulation of experience in long-term production practices. Only external shocks will cause them to reconfigure factors; therefore, the effect of factor allocation change may be absorbed by other external shocks.

The mechanism path of technical efficiency change is not clear and the coefficient of technical efficiency is negative. Technical efficiency reflects the gap between one province and frontier provinces at a certain time. The evidence shows that the differences in China's agricultural GTFP between provinces show an increasing trend [13], which means that the technical efficiency gap becomes larger over time. Therefore, the contribution of technical efficiency to GTFP is negative. Another possible reason is that most farmers have not been able to adjust their agricultural management methods quickly enough to the 
technological changes caused by mechanization, resulting in a reduction in the refinement of agricultural production.

\section{Conclusions}

This paper selected the panel data of 30 provinces in China from 2001 to 2019, used the stochastic frontier analysis method of the output-oriented distance function to measure the planting GTFP based on net carbon sinks, and further discussed the influence and mechanism of mechanization on planting GTFP using the instrumental variable method, recursive model and spatial econometric method. The main conclusions drawn from this paper are as follows:

Firstly, regardless of the analysis of different regions or different degrees of mechanization, mechanization can significantly promote planting GTFP. The impact of mechanization on GTFP depends on three aspects: the emissions increase effect caused by energy consumption, the emissions reduction effect caused by the optimization of agriculture chemical inputs and the sinks increase effect caused by the increase in yield. From the perspective of input-output, GTFP is reduced by the first aspect and improved in the latter two aspects. The results show that the influence of the latter two aspects is greater than that of the first; although mechanization consumes more energy, it has a stronger positive impact.

Secondly, the mechanism path is mainly reflected in technology progress and spatial spillover, while the path of operation scale expansion, factor allocation optimization and technical efficiency change is not verified. Through technology progress, mechanization improves the efficiency of traditional energy utilization, changes the traditional factor input structure, and optimizes the energy consumption structure by increasing the utilization of renewable energy, and then promoting planting GTFP. The mechanism path of spatial spillover is embodied in a cross-regional machinery operation that disseminates advanced farming experience and management technology. Due to the nature of constant returns to scale in agriculture, the path of operation scale expansion is not confirmed. The path of factor allocation optimization is not verified because farmers are rational, economic people [47], and their current factor allocation state is already optimal through the effect of learning and the accumulation of experience in long-term production practices. Only external shocks will cause them to reconfigure factors; therefore, the effect of factor allocation change may be absorbed by other external shocks. Since most farmers cannot adjust their agricultural management methods quickly enough to technology changes caused by mechanization, the technical efficiency gap becomes larger over time, which causes the path of technical efficiency change to become less clear, and the coefficient of technical efficiency is negative.

Thirdly, with the improvement in mechanization level, the promotion effect of mechanization on planting GTFP will become more clear. When the degree of mechanization is low, mechanization mainly shows the effect of the technology progress. With the promotion of the mechanization degree, the marginal effect of technology progress has a decreasing trend, while its factor allocation effect and economies of scale effect begin to appear. At the same time, the superposition of the technical efficiency change effect and spatial spillover effect continually strengthens the promotion effect of mechanization on planting GTFP.

Based on the conclusion of this study, the following policy recommendations can be extended:

Firstly, policymakers should accelerate the improvement of mechanization in the planting industry and realize the leap of mechanization development. Planting GTFP can be promoted by expanding the use of machinery. For regions with a high level of mechanization, the renewal and replacement of existing machinery, and the promotion of machinery with a lower energy consumption to improve planting GTFP, is crucial. For other areas, especially in non-grain-producing provinces, the mechanization level is still low because of topographic factors or crop structure factors, which mean that the promotion of mechanization is weaker than that of other regions. Therefore, it is valuable to develop 
appropriate and suitable machinery for these areas to promote their planting GTFP and the quality of planting development.

Secondly, efforts should be made to strengthen coordination and cooperation between adjacent regions, in order to realize the rational flow and scientific allocation of agricultural machinery resources and give full play to the positive spatial spillover effect of mechanization. For provinces with similar crop planting types, it is significant to guide and promote cross-regional operations through information distribution, to ensure that the positive externality of mechanization is highlighted.

Thirdly, it is necessary to appropriately increase investment in transportation infrastructure to improve the traffic and operation conditions of agricultural machinery effectively. The promotion of transportation infrastructure can improve mechanization levels by optimizing the road conditions of agricultural machinery operations and reducing traffic costs.

There are also some potential limitations in this paper. First, in terms of sample selection, this research was conducted at the provincial level; future studies could conduct investigations at the county level, potentially with richer data and more accurate results. Second, in terms of research depth, we used the comprehensive mechanization rate to represent agricultural mechanization. Specifically, mechanization in different production stages, such as sowing and reaping, may have different impacts on planting GTFP; therefore, it is worth studying through dividing mechanizations into different stages or different methods. Third, in terms of research scope, the findings of this paper require further verification in other countries or regions.

Author Contributions: Y.Z. (Yingyu Zhu) developed the design of the manuscript and prepared the draft manuscript. Y.Z. (Yan Zhang) designed the structure of the final manuscript and supervised the final version of the manuscript. H.P. reviewed the scientific literature and prepared the data and figures. All authors have read and agreed to the published version of the manuscript.

Funding: This research was funded by the Science Foundation of Ministry of Education of China (grant number 19YJA880083), National Natural Science Foundation of China (grant number 71703106), and China Postdoctoral Science Foundation (grant number 2018M631823).

Institutional Review Board Statement: Not applicable.

Informed Consent Statement: Not applicable.

Data Availability Statement: The datasets analyzed during the current study are available from the corresponding author on reasonable request.

Conflicts of Interest: The authors declare no conflict of interest.

\section{References}

1. Xia, F.; Xu, J. Green total factor productivity: A re-examination of quality of growth for provinces in China. China Econ. Rev. 2020, 62, 101454. [CrossRef]

2. Ismael, M.; Srouji, F.; Boutabba, M.A. Agricultural technologies and carbon emissions: Evidence from Jordanian economy. Environ. Sci. Pollut. Res. 2018, 25, 10867-10877. [CrossRef] [PubMed]

3. Akbar, U.; Li, Q.; Akmal, M.A.; Shakib, M.; Iqbal, W. Nexus between agro-ecological efficiency and carbon emissions transfer: Evidence from China. Environ. Sci. Pollut. Resh. 2021, 28, 18995-19007. [CrossRef] [PubMed]

4. She, W.; Wu, Y.; Huang, H.; Chen, Z.; Cui, G.; Zheng, H.; Guan, C.; Chen, F. Integrative analysis of carbon structure and carbon sinks function for major crop production in China's typical agriculture regions. J. Clean. Prod. 2017, 162, 702-708. [CrossRef]

5. Song, M.; Li, H. Total factor productivity and the factors of green industry in Shanxi Province, China. Growth Chang. 2020, 51, 488-504. [CrossRef]

6. Luo, F.; Guo, Y.; Yao, M.; Cai, W.; Wang, M.; Wei, W. Carbon emissions and driving forces of China's power sector: Input-output model based on the disaggregated power sector. J. Clean. Prod. 2020, 268, 121925. [CrossRef]

7. Wang, X.; Yamauchi, F.; Huang, J. Rising wages, mechanization, and the substitution between capital and labor: Evidence from small scale farm system in China. Agric. Econ. 2016, 47, 309-317. [CrossRef]

8. Tang, L.; Wang, D. Optimization of County-Level Land Resource Allocation through the Improvement of Allocation Efficiency from the Perspective of Sustainable Development. Int. J. Environ. Res. Public Health 2018, 15, 2638. [CrossRef] 
9. Tan, M.; Zheng, L. Increase in economic efficiency of water use caused by crop structure adjustment in arid areas. J. Environ. Manag. 2019, 230, 386-391. [CrossRef]

10. Balk, B.M. Scale Efficiency and Productivity Change. J. Prod. Anal. 2001, 15, 159-183. [CrossRef]

11. Solow, R.M. Technical change and the aggregate production function. Rev. Econ. Stat. 1957, 39, 312-320. [CrossRef]

12. Wang, X.; Sun, C.; Wang, S.; Zhang, Z.; Zou, W. Going Green or Going Away? A Spatial Empirical Examination of the Relationship between Environmental Regulations, Biased Technological Progress, and Green Total Factor Productivity. Int. J. Environ. Res. Public Health 2018, 15, 1917. [CrossRef] [PubMed]

13. Liu, D.; Zhu, X.; Wang, Y. China's agricultural green total factor productivity based on carbon emission: An analysis of evolution trend and influencing factors. J. Clean. Prod. 2021, 278, 123692. [CrossRef]

14. Cullinane, K.; Wang, T.; Song, D.; Ji, P. The technical efficiency of container ports: Comparing data envelopment analysis and stochastic frontier analysis. Transp. Res. Part A Policy Pract. 2006, 40, 354-374. [CrossRef]

15. Gong, B.; Sickles, R.C. Finite sample evidence on the performance of stochastic frontiers and data envelopment analysis using panel data. J. Econ. 1992, 51, 259-284. [CrossRef]

16. Coelli, T.J.; Perelman, S. A comparison of parametric and non-parametric distance functions: With application to European railways. Eur. J. Oper. Res. 1999, 117, 326-339. [CrossRef]

17. Moreira, V.H.; Bravo-Ureta, B.E. Total factor productivity change in dairy farming: Empirical evidence from southern Chile J. Dairy Sci. 2016, 99, 8356-8364. [CrossRef]

18. Liu, J.; Dong, C.; Liu, S.; Rahman, S.; Sriboonchitta, S. Sources of Total-Factor Productivity and Efficiency Changes in China's Agriculture. Agriculture 2020, 10, 279. [CrossRef]

19. Xu, X.; Huang, X.; Huang, J.; Gao, X.; Chen, L. Spatial-Temporal Characteristics of Agriculture Green Total Factor Productivity in China, 1998-2016: Based on More Sophisticated Calculations of Carbon Emissions. Int. J. Environ. Res. Public Health 2019, 16, 3932. [CrossRef]

20. Chen, Y.; Miao, J.; Zhu, Z. Measuring green total factor productivity of China's agricultural sector: A three-stage SBM-DEA model with non-point source pollution and CO2 emissions. J. Clean. Prod. 2021, 318, 128543. [CrossRef]

21. Zhan, J.; Tian, X.; Zhang, Y.; Yang, X.; Qu, Z.; Tan, T. The Effects of Agricultural R\&D on Chinese Agricultural Productivity Growth: New Evidence of Convergence and Implications for Agricultural R\&D Policy. Can. J. Agric. Econ. 2017, 65, 453-475. [CrossRef]

22. Liu, F.; Lv, N. The Threshold Effect Test of Human Capital on the Growth of Agricultural Green Total Factor Productivity: Evidence from China. Int. J. Electr. Eng. Educ. 2021, in press. [CrossRef]

23. Fang, L.; Hu, R.; Mao, H.; Chen, S. How crop insurance influences agricultural green total factor productivity: Evidence from Chinese farmers. J. Clean. Prod. 2021, 321, 128977. [CrossRef]

24. Battese, G.E.; Coelli, T.J. Frontier production functions, technical efficiency and panel data: With application to paddy farmers in India. J. Prod. Anal. 1992, 3, 153-169. [CrossRef]

25. Qing, Y.; Chen, M.; Sheng, Y.; Huang, J. Mechanization services, farm productivity and institutional innovation in China. China Agric. Econ. Rev. 2019, 11, 536-554. [CrossRef]

26. Wang, Q.; Jiang, R. Is China's economic growth decoupled from carbon emissions? J. Clean. Prod. 2019, 225, 1194-1208. [CrossRef]

27. Lu, H.; Xie, H.; He, Y.; Wu, Z.; Zhang, X. Assessing the impacts of land fragmentation and plot size on yields and costs: A translog production model and cost function approach. Agric. Syst. 2018, 161, 81-88. [CrossRef]

28. Wu, Y.; Xi, X.; Tang, X.; Luo, D.; Gu, B.; Lam, S.; Peter, M.; Chen, D. Policy distortions, farm size, and the overuse of agricultural chemicals in China. Proc. Natl. Acad. Sci. USA 2018, 115, 7010. [CrossRef]

29. Liu, Y.; Zou, L.; Wang, Y. Spatial-temporal characteristics and influencing factors of agricultural eco-efficiency in China in recent 40 years. Land Use Policy 2020, 97, 104794. [CrossRef]

30. Takeshima, H.; Adhikari, R.P.; Shivakoti, S.; Kaphle, B.D.; Kumar, A. Heterogeneous returns to chemical fertilizer at the intensive margins: Insights from Nepal. Food Policy 2017, 69, 97-109. [CrossRef]

31. Yu, Y.; Jiang, T.; Li, S.; Li, X.; Gao, D. Energy-related $\mathrm{CO}_{2}$ emissions and structural emissions' reduction in China's agriculture: An input-output perspective. J. Clean. Prod. 2020, 276, 124169. [CrossRef]

32. Shi, M.; Paudel, K.; Chen, F. Mechanization and efficiency in rice production in China. J. Int. Agric. 2021, 20, 1996-2008. [CrossRef]

33. Tang, Y.; Lu, X.; Yi, J.; Wang, H.; Zhang, X.; Zheng, W. Evaluating the spatial spillover effect of farmland use transition on grain production-An empirical study in Hubei Province, China. Ecol. Indic. 2021, 125, 107478. [CrossRef]

34. Cui, Y.; Khan, S.U.; Deng, Y.; Zhao, M.; Hou, M. Environmental improvement value of agricultural carbon reduction and its spatiotemporal dynamic evolution: Evidence from China. Sci. Total. Environ. 2021, 754, 142170. [CrossRef] [PubMed]

35. Hayes, A.F. Beyond Baron and Kenny: Statistical Mediation Analysis in the New Millennium. Commun. Monogr. 2009, 76, 408-420. [CrossRef]

36. Gong, B. Agricultural reforms and production in China: Changes in provincial production function and productivity in 1978-2015. J. Dev. Econ. 2018, 132, 18-31. [CrossRef]

37. Cao, K.H.; Birchenall, J.A. Agricultural productivity, structural change, and economic growth in post-reform China. J. Dev. Econ. 2013, 104, 165-180. [CrossRef]

38. Chari, A.; Liu, E.M.; Wang, S.; Wang, Y. Property Rights, Land Misallocation, and Agricultural Efficiency in China. Rev. Econ. Stud. 2021, 88, 1831-1862. [CrossRef] 
39. Kalirajan, K.P.; Obwona, M.B.; Zhao, S. A Decomposition of Total Factor Productivity Growth: The Case of Chinese Agricultural Growth before and after Reforms. Am. J. Agric. Econ. 1996, 78, 331-338. [CrossRef]

40. Li, Z.; Zhang, H. Productivity Growth in China's Agriculture During 1985-2010. J. Int. Agric. 2013, 12, 1896-1904. [CrossRef]

41. Toma, P.; Miglietta, P.P.; Zurlini, G.; Valente, D.; Petrosillo, I. A non-parametric bootstrap-data envelopment analysis approach for environmental policy planning and management of agricultural efficiency in EU countries. Ecol. Indic. 2017, 83, 132-143. [CrossRef]

42. Tian, Y.; Zhang, J.; He, Y. Research on Spatial-Temporal Characteristics and Driving Factor of Agricultural Carbon Emissions in China. J. Int. Agric. 2014, 13, 1393-1403. [CrossRef]

43. Chen, Y.; Li, M.; Su, K.; Li, X. Spatial-Temporal Characteristics of the Driving Factors of Agricultural Carbon Emissions: Empirical Evidence from Fujian, China. Energies 2019, 12, 3102. [CrossRef]

44. Li, N.; Jiang, Y.; Yu, Z.; Shang, L. Analysis of Agriculture Total-Factor Energy Efficiency in China Based on DEA and Malmquist indices. Energy Proced. 2017, 142, 2397-2402. [CrossRef]

45. Reza Anik, A.; Rahman, S.; Sarker, J.R. Five Decades of Productivity and Efficiency Changes in World Agriculture (1969-2013). Agriculture 2020, 10, 200. [CrossRef]

46. Jiang, M.; Hu, X.; Chunga, J.; Lin, Z.; Fei, R. Does the popularization of agricultural mechanization improve energy-environment performance in China's agricultural sector? J. Clean. Prod. 2020, 276, 124210. [CrossRef]

47. Popkin, S.L. The Rational Peasant; University of California Press: Berkeley, CA, USA, 1979; pp. 1-31. [CrossRef] 